\title{
Historical Antirealism and the Past as a Fictional Model
}

\author{
David Černín*
}

Received: 15 June 2018 / Accepted: 28 January 2019

Abstract: This paper focuses on the discipline of history, its methods, subject, and output. A brief overview of contemporary analytic philosophy of history is provided, followed by critical discussion of historical realism. It is argued that the insistence on the idea that historians inquire into the real past and that they refer to the actual past entities, events, or agents is widely open to sceptical objections. The concept of an abstract historical chronicle of past events which are explained or retold by historians is identified as misleading. The idea of historical antirealism is then introduced. It is argued that in the centre of historian's attention are present phenomena that are identified as historical evidence and require historical explanation. Historical explanation consists of constituting an historical pasta fictional model that accounts for present data. The identification process of historical evidence and the discursive nature of historical enterprise are analysed and accompanied by several concrete examples. According to historical antirealism, historians are not interested in the real past, but in the present empirical data. In their pursuit of historical knowledge, they produce fictional models - an historical past. Lastly, several common caveats against historical antirealism are addressed. The historical antirealism is presented as a viable fictionalist account of the historical inquiry that is capable of avoiding

* University of Ostrava

- FF OU - The Centre for Research in Medieval Society and Culture (VIVARIUM); Department of Philosophy, Faculty of Arts, University of Ostrava, Reální 5, 701 03 Ostrava, Czech Republic

$\bowtie$ cernin.d@gmail.com

() The Author. Journal compilation (C) The Editorial Board, Organon F.

This article is distributed under the terms of the Creative Commons Attribution-NonCommercial 4.0 International Public License (CC BY-NC 4.0). 
sceptical attacks on historical method and it is argued that antirealism allows history to retain its worth as a distinctive kind of scientific discipline.

Keywords: Analytic philosophy of history; antirealism; evidence; explanation; Goldstein; history; model.

\section{Outset}

This paper aims to reassess the philosophical conceptions of historical inquiry, to identify some problematic ideas that are more or less present in contemporary philosophy of history (historical realism), to explore controversial alternative (historical antirealism), its relations to fictionalism, and to highlight its possible merits. The paper proceeds by the introduction of the analytical philosophy of history followed by the assessment of historical realism and historical narrativism, which introduces fictional elements to the discourse. Then it moves to the preferred alternative - the historical antirealism and the final part answers the most common caveats against the historical antirealism.

A fictionalist approach to the wide range of entities involved in the process of scientific explanation is a notoriously attractive standpoint. Certain entities (e.g. highly idealised models of atoms, clusters of space bodies, social institutions, or historical periods) may be regarded as fictional by philosophers. Nonetheless, as long as these models ${ }^{1}$ allow scientists to achieve an understanding of our world and present phenomena, to test their assumptions or predictions by the means of controlled experiments, to explain various observations which are accommodated by the model, or to produce results affecting our daily practices, we generally consider these fictions to be useful and therefore vindicated. Fictional and idealised models are often in the very centre of scientific discussions and they are continuously changed or adjusted to better account for the phenomena in question. This fluid nature of scientific models compels some philosophers to treat

1 Models in this paper are understood as 'a work of fiction' in the same sense as presented by Nancy Cartwright, see (Cartwright 1983, 153). For further discussions, see (Hartmann et al. eds. 2008). 
them as fictional entities, relieved of the ontological burden, which play important roles in many scientific disciplines.

Fictional entities help scientists to apprehend and simplify complex systems, to make predictions, to mediate the fruits of their research process to the public, or they can be employed and utilised by other scientific disciplines. The very act of constituting a fictional entity is scarcely the final step for researchers to do, since creating a fiction is certainly not regarded as the goal of any scientific endeavour. However, some disciplines can become easily contested in this respect. A fictionalism and its associated issues are often brought up in relation to various disciplines that are focused on the past entities and events. This entails not only the history ${ }^{2}$ and historiography but also some natural sciences and subfields, like cosmogony, geology, evolutionary biology, etc. ${ }^{3}$ The former group is studied by philosophers of history and philosophers of historiography, ${ }^{4}$ while the latter is the subject of the philosophy of science. The parallels between natural sciences and human history are continuously discussed by scientists and philosophers. ${ }^{5}$ At the same time, philosophers of historiography appreciate

2 By history in this paper I mean the discipline of history and historical inquiry, not the course of past events itself. Cf. (Tucker ed. 2009, 1-6). In this context, it is therefore meaningless to ask questions about the meaning of history, the destination of history, or about its predictive capabilities. The real course of past events will be referred to simply as the past.

3 This idea is clearly expressed by David L. Hull for whom the cosmogony, geology, palaeontology, and human history 'are the four most important historical disciplines' (Hull 1975, 264).

4 By philosophy of history or philosophy of historiography, I mean especially contemporary Anglo-Saxon philosophical tradition which aims at explaining the practice of history. This discipline is variously called analytic philosophy of history, epistemological philosophy of history, critical philosophy of history, or philosophy of historiography. It is, therefore, very different from substantial or speculative philosophy of history, which entails authors like Francis Fukuyama, Arnold J. Toynbee, or Karl Marx. This paper does not focus on the speculative philosophy of history.

5 The philosopher of biology David Hull and his 1975 article is a great example. He also joined discussions about the aims and methods of the history of science in (Hull 1979). Prominent evolutionary biologist Richard Lewontin also pointed out 
the insight into scientific practices brought by prominent philosophers of science like N. Cartwright or W.V.O. Quine and they try to apply their conclusions to the history and historiography. ${ }^{6}$

The historical enterprise, its goals, methods, rules, merits, and limitsall those lie in the centre of many philosophical disagreements. At first glance, it may seem trivial to claim that the history focuses on the past and the historians are supposed to discover and explain the past facts to their audience. Historians are interested in the actions of historical agents and they should mediate their reasoning to readers. They are supposedly meant to find the reasons for wars, revolutions, migrations, unexpected victories in elections, or economic crises. This entails the field of historical explanation - the longstanding debate, which can trace its origins to the C.G. Hempel's influential paper "The Function of General Laws in History" (Hempel 1942). Nonetheless, it has been contested that works of historians do not represent the most illustrious cases of covering law application. ${ }^{7}$ Still, the interest in the components of historical explanation lasts to these days, it often intersects the narrativist philosophy of history ${ }^{8}$ and it is also echoed

striking similarities between human history and evolutionary biology in (Lewontin 1991). See also (Wilkins 2009).

${ }_{6}$ Aviezer Tucker, an influential philosopher of historiography, draws a lot of inspiration from the philosophy of biology and he even joined their discussions; see paper (Tucker 2011). He also approaches the study of historiography with the concept of Quine's naturalized epistemology in mind; see (Tucker 2001, 49) or (Tucker 2004, 9). M.G. Murphey mentions N. Cartwright as the important influence on his work and the reason for his abandonment of Hempelian paradigm; see (Murphey 2009, x). The analytic philosopher Paul A. Roth also focuses both on natural sciences, Quine's intellectual legacy, and the narrativist philosophy of history at the same time.

7 (Hempel 1942) was written by Hempel shortly after his emigration to the USA. This paper has drawn the attention of many Anglo-Saxon philosophers to the discipline of history and it is discussed to this day. See (Mandelbaum 1961; Wright 1971; Murphey 1986), etc. Contemporary historical accounts of the analytic philosophy of history usually start with this paper and critical reaction to it, see (Ankersmit 1986; O'Sullivan 2006; Kuukkanen 2015).

8 By narrativist philosophy, I refer to the philosophical tradition represented by W.B. Gallie, A.C. Danto, H. White, F. Ankersmit, etc. 
in the discussions concerning historical explanation and the role of general laws in natural sciences. ${ }^{9}$

The narrativist philosophers of history often herald their own linguistic turn in the philosophy of history and they openly focus on the language historians use. ${ }^{10}$ The act of historical writing and the linguistic structure historians impose on the past stand in the centre of their attention. Narrativists stress the choices historians make when presenting their accounts of historical events. Historical enterprise is basically a kind of literature and storytelling while a spatiotemporal and cultural background of the historian - storyteller vastly influences the final outcome. Narrativism thus allows for a diversity of accounts we find in the field of history and historiography and which we cannot easily disregard.

Nonetheless, even narrativist philosophers of history do require some connection to the past historians are writing about. In order to provide a narrative explanation, historians and scientists ${ }^{11}$ must possess some knowledge of the past events and facts that are chronologically ordered into sets, possibly in the form of singular factual statements. These basic sets are a necessary prerequisite for any narrative explanation and they are generally called "a chronicle" by narrativist philosophers. ${ }^{12}$ Term "chronicle," meaning singular non-causal factual statements as a prerequisite for writing explanatory history or narrative, is also to be found in the works of Morton White (see White M. 2005, 40).

$9 \quad$ E.g. Alexander Rosenberg stresses the fact that historical explanation is a specific case of explanation in (Rosenberg 2007, 129-31); see also (Rosenberg 2000). Rosenberg is known for being strongly critical of "philosophers of history" and "history buffs," however, his criticism usually pertains to the speculative philosophy of history and he does not refrain from borrowing concepts and distinctions from critical philosophy of history which is "a division of philosophy whose relevance to biology may now be apparent" (Rosenberg 2000, 151).

10 An exemplary historical narrative of the narrativism and its development is provided by (Ankersmit 1986).

11 Paul Roth argues that even evolutionary biology employs narrative explanations since every retrospective explanation (e.g. how an adaptive mutation came to be) is an essentially narrative explanation which must necessarily proceed by the chronological sequencing of preceding events, i.e. creating a narrative. See (Roth 2017).

12 See (White H. 1973). For critical discussion, see (Murphey 2009, 103-34). 
The narrativist philosophers of history use the distinction between a chronicle and a story or history to highlight the main focus of their approach to historical enterprise. The mere chronological ordering of events does not constitute a proper historical account, it does not explain anything, and does not tell a story:

The story transforms the events from the meaninglessness of their serial arrangement in a chronicle into a hypotactically arranged structure of occurrences about which meaningful questions (what, where, when, how, and why) can be asked. (White H. 1975, 59)

Even Hayden White compares this task of historians to the creation of model:

But this fashioning is a distortion of the whole factual field of which the discourse purports to be a representation - as is the case in all model-building. (White H. 1975, 60)

This layer of model-building (the transformation of a chronicle into proper history) lies in the centre of narrativist's attention and it does pose a truly fascinating theoretical issue on its own.

However, the very idea of a chronicle of past events, providing building blocks for historical narratives, should be particularly troubling for historians and scientists. Neither evolutionary biologists nor historians will ever have the full "chronicle" of past entities at their disposal. This chronicle itself could be considered as an idealisation or fiction and as such, it also begs an important question: How do we obtain the knowledge of the past events and entities? Is it a knowledge of the real past? Is a chronicle factual or already fictional? Consequently, the very same question pertains also to the discussion about historical explanation. It will be shown that this is not merely a question regarding the context of discovery of sole historical fact. On the contrary: it is a question about the more fundamental level of modelbuilding that precedes the formation of a chronicle.

\section{Historical realism and invitation for scepticism}

Both narrativist philosophy of history and analytic philosophy of history still show some residual signs of naïve historical realism when accounting 
for the discipline of history. This can be quite surprising in the case of narrativist philosophy, which does offer a more relativistic portrait of historians exercising their liberties when writing historical narratives. In the words of Frank Ankersmit: "the historical narrative is a complex linguistic structure specially built for the purpose of showing part of the past" (Ankersmit 1986, 19). At the same time, Ankersmit rejects naïve historical realism as inherently flawed as well as the majority of contemporary philosophers and theoreticians of history. ${ }^{13}$

Historical realism does invoke conception akin to the correspondence theory of truth. Historians are considered to be inquiring into the real past and the touchstone for their theories are real past events as they actually happened. This may even appear as an unproblematic statement: historians inform us about events, people, cities, buildings, pieces of art, organisms, and generally about the entities we encounter in everyday life and we consider them to be real. None of these objects is abstract in any way and we do not require historians to describe Caesar as a real human with two legs and two arms so we can imagine him properly. The majority of historical events is observable in principle (see Murphey 2009, 10-14) and therefore we can imagine them as represented by historians and historical texts. According to the historical realists, historical explanation, in any of its form, is bound to explain the processes in the past.

On the other hand, nobody would ever claim that historians do have any mysterious access to the past. ${ }^{14}$ Historians do not time-travel and they

13 There are various philosophical approaches to a history that try to avoid naïve historical realism: Some philosophers of history do not consider the discussions about historical realism/antirealism relevant, see (Tucker 2001, 52), while others subscribe to moderate versions, like "constructivist realism," see (Murphey 2009, 13). Maurice Mandelbaum could be portrayed as defending position akin to historical realism in the case of "general history", but not in the case of "special histories" (Mandelbaum 1977). Although historical realism is scarcely defended, there are some exceptionse.g. Sir Geoffrey Elton, an historian whose texts on the historical method are considered to favour historical realism.

14 There is, of course, a rather problematic case of R.G. Collingwood and his notion of "re-enactment," which is commonly interpreted as a metaphysical link to the thought of historical agents, through which historians can re-think or re-live the past, see e.g. (Tucker 2004, 200-207). However, there are also interpreters who 
do not observe the events they are writing about. At the same time, they do not (generally speaking) conduct experiments. There are, of course, exceptions to both of these statements: historians can write about the events they themselves experienced (observed) ${ }^{15}$ they can work (in the case of recent history) with movie footage, or they can interview living witnesses. ${ }^{16}$ They can even employ the methods of experimental archaeology which make use of laboratory equipment and modern methods to test and replicate various artefacts our ancestors were apparently using during their lifetime. Various types of chemical and spectrographic analyses of historical relicts are also widely used to recover significant data. All of these methods are genuinely historical, they are successfully and critically employed, and neither of these invites any fatal criticism which could uncover it as profoundly unscientific. However, none of these methods does interact directly with the real past in any way.

At the same time, many entities that are postulated by historians and that are said to affect past events are admittedly abstract constructs which defy precise definition. Ancient Greek philosophy is a common term in many texts inquiring into the history of philosophy. Nonetheless, it does not aspire to describe all Ancient Greeks who have ever philosophised. Neither does it seek to explain all present artefacts (especially texts) which are identified as instances of this philosophy. Historians of philosophy are rather trying to refine the contemporary notion itself upon the basis of a limited number of selected texts and the very process of selection of canonical texts is an argumentative strategy in itself (see Guéroult 1969). Unanimous consensus on the canonical texts and their interpretations does not exist but we can still talk about the Ancient Greek philosophy as influencing future texts,

understand Collingwood more in lines with constructivism and even antirealism; see (Nielsen 1981), (Dussen 2012), or (Goldstein 1996).

15 However, simply "remembering something" is definitely not the same as "having an historical account of something." Historical inquiry entails critical approach to evidence and memories of witnesses or historians can be used as such evidence.

16 The oral history has come a long way since the time of Herodotus. Interviewing witnesses and contemporaries is now a highly systematic process which takes a heed of other disciplines, including psychology, in order to filter out possible personal biases, etc.

Organon F 26 (4) 2019: 635-659 
authors, or ideas. Many terms commonly used to denote specific periods like the Renaissance, the Cold War, the Thaw, or the Thirty Years' War have been analysed by the philosophers of history. These colligatory terms help us to make the past more comprehensible, even though their clear delimitation is not firmly given. ${ }^{17}$

Some philosophers have tried to answer the caveats against historical realism by compromise. Maurice Mandelbaum established a distinction between general history and special histories (Mandelbaum 1977, 162-65). He holds that general history is interested in the continual existence of a society (e.g. France), while special histories (e.g. French literature of certain period) are interested in the collection of separate works, whose identification is theory-laden. These considerations lead him to a conclusion that special histories cannot claim objectivity in any way. However, the claim that historians recognise societies as entities having continuous existence has been contested by other philosophers of history. ${ }^{18}$ Michael Oakeshott directly states that it is easy for philosophers to challenge even the seemingly unambiguous notions like England since the subject of history is not a datum but it is established in the course of historical inquiry and the identification of its subject is entirely in the hands of the historian (Oakeshott 2004, 404406). Contemporary historical accounts of any European country are narratives of many different societies that were radically changing as well as their own understanding of historical identity and continuity. Some ancient societies are even notoriously difficult to identify as continuous entities since they have left only a neglectable amount of traces and their exact identity is a mystery (e.g. many Mesoamerican cultures). Interestingly, Mandelbaum does not mention historical agents as entities having continuous existence in time, and persons are usually studied in relation to their society (Mandelbaum 1977, 207-208).

The discussions concerning the historical realism are also reflected in the contemporary debates about historical representationalism and historical non-representationalism which have inherited many recurring issues. Comprehensive account showing the development of this debates was

17 The concept of colligatory terms is a persistent topic in analytic philosophy of history. For the most recent overview see (Kuukkanen 2015, 97-115).

18 See direct attack on Mandelbaum's distinction by (Goldstein 1986, 84-87). 
provided by Eugen Zeleňák (see Zeleňák 2018). His overview of more radical historical representationalism follows:

According to this view, historical works should correspond to the past, if not perfectly, then at least as faithfully as possible. There should be no subjective preconceptions, no prejudicial intrusions, and no unnecessary external factors entering the process of learning about the past. Historical works should give us (relatively) direct access to the past. (Zeleňák 2018, 118)

Although the idea of an historian as a scientist who is uncovering, reporting, and explaining the past may seem unproblematic at first glance, we can see that many philosophers have denounced this option. The criticism of the idea of historical realism may seem like a direct consequence of sceptical reasoning - the past is gone; therefore, we cannot know it. It does apparently stem from the fact that our knowledge of the past is limited by the available evidence which suffers from information decay over time. Consequently, since we cannot access the past directly and since we do not generally possess all necessary evidence, we cannot fully know what really happened in the real past. Thus, according to historical realism, significant portions of history as a discipline and science would be seriously restricted or even rendered impossible. However, we can clearly see that this is not the case. Historians and other scientists are successful in creating theories and narratives which have significant explanatory value, despite the fact they are not explaining the past events and entities themselves. It is actually the historical realism itself that invites scepticism about the historical methodology and their findings. Setting the real past as a touchstone for historical inquiry is to expose many (if not all) historical theories and narratives to justifiable criticism for being too speculative. In some cases, we may have overwhelming evidence at our disposal and we may be convinced that some statements about the real past are beyond doubt, however, this does not hold for a vast amount of historical narratives and does not account for diverse historical narratives or theories of "the same" subject. Even the partial realism (e.g. Mandelbaum's distinction between objective general history and relative special histories) seems to share these issues. Should we abandon the historical realism, what alternatives do we have? Can we imagine history without the past? We will now explore the possible merits of historical antirealism.

Organon F 26 (4) 2019: 635-659 


\section{Historical antirealism and banishment of the past}

To say that the discipline of history is not interested in the past may seem counter-intuitive and even fatal to historians and philosophers. To fully appreciate historical antirealism, several issues must be clarified first:

(1) Historical antirealism is not a negative claim about the ontological status of the real past. It only states that the real past is not a subject of historical inquiry and the ontological status of entities is not a pressing subject for historians to discuss. It is both possible to hold some kind of realism about the past and entities in the past and to be an historical antirealist, claiming that this real past is not the subject of the discipline of history. It is relieved of burdensome realistic load.

(2) Historical antirealism is not saying that anything goes in the field of history. Historians are bound to provide explanations and these explanations must adhere to similar epistemic virtues (e.g. coherence, simplicity, scope, accuracy, etc.) as explanations in other areas of human knowledge. Historians are also limited by available data and accepted evidence. There is, of course, space for competing theories and disagreements among historians, however, this does not mean that historical inquiry is not a highly specialised form of knowledge that expands its achievements.

(3) Historical antirealism is not limited to only some aspects of historical disciplines. It aims to encompass historical explanations, historical narratives, historical writing, historical research and its methods, historical representation, and various historical disciplines, including ancillary disciplines, and fields. It includes the history of ancient pottery as well as poetry, it includes national political histories and the history of modern philosophy. In other words, it does not accept Mandelbaum's distinction between general history and special histories and it strives to be inclusive, not exclusive.

Historical antirealism does not focus solely on the final products of historians that are intended for a wider audience. This was, according to L.J. 
Goldstein, the common mistake made by both the covering law theoreticians and the narrativist philosophers of history alike. The history is not exclusively about writing and explaining. Before we can explain the French Revolution or write about the Peloponnesian War we must first establish them as historical entities. This is done by identifying relevant data, classification of evidence, source criticism, or by employing many other methods, available to the historian.

Goldstein criticised the narrativist philosophers of history and the analytic philosophers of history for not going beyond the texts and textbooks historians produce. It is true that historical texts are the most visible to non-historian consumers, however, they do not reveal what is unique about the historical enterprise as the way of knowing. He coined the distinction between the superstructure of history (the finished product, usually in narrative form, intended for layman consumers) and the infrastructure of history (methods and reasoning employed by historians in the course of their inquiry). Goldstein argued that philosophers have focused almost exclusively on the superstructure of history and ignored the infrastructure of history (Goldstein 1976, 139-82). The discipline of history is not about explaining the pre-given sets of facts about the past, it is not about framing the individual parts of chronicle into a single narrative. On the contrary, historians constitute the historical past (i.e. not the real past) before they can explain it or interpret it. This constitution of an historical past is an intellectual activity that is largely dependent on the evidence contemporary historians can identify and utilize, on the accepted procedures of historical inquiry, and on the current status of historical knowledge or discourse. The real past is virtually thrown out of the equation by historical antirealism and the roles of contemporary methods of scientific historiography and community of historians are stressed. Discussing Collingwood's Roman Britain and his conclusion from the solitary gravestone to the presence of the Irish colony (colony that "he called to the existence"), Goldstein states:

It is all well and good to say that Collingwood's statement is true only if there really was such a colony, but that is to say something that has no consequence for historical inquiry; it simply expresses the hope that historical past is identical with the real past. (Goldstein 1996, 334) 
It is clear that the act of postulating the entire colony from a single gravestone as a piece of evidence is not simply an abstraction since it rather adds than abstracts.

Historical past resembles the antirealist conception of fictional models in science in a striking manner. It is created by the professionals to explain specified sets of present (encountered) phenomena. The Goldstein's point can be made even more illustrative if we apply it to the non-textual historical models. It is true that the stereotypical output of historical inquiry is a book or an article. However, we can easily encounter small-scale spatial models of historical cities like Prague in the $14^{\text {th }}$ century. Such model is supposed to represent the highly idealised state of the specific city in the specific historical past, although it is not an exact full-scale reconstruction, neither it aims to represent everything exactly as it was in the real past since such accuracy is not attainable or even desirable. Individual building blocks of the model are fictional, abstract, and highly idealised. Nonetheless, various parts of the given model are based upon the evidence of a different kind. Some buildings may be included in the model on the basis of available written records or, usually incomplete, archaeological findings. Other structures may have survived to this day, although their appearance in the model may have been adjusted according to other relevant evidence. Provided we are admiring such model in a museum, some pieces of empirical data identified as an evidence are usually located nearby and they are basically substituting the role of footnotes in historical texts. The models of historical cities in the past can explain to us why the contemporary centre of the city is suddenly cut in half by the old fortification. At the same time, we can seek an explanation of some relations between various entities that become apparent in the model, for example, the locations of certain specialised structures (i.e. a division of city's quarters) or their relative distances. Such model does account for an available and identified evidence, however, does it really have to correspond to some particular state of the city in the real past? This suggestion, once again, expresses the hope that the historical past is identical with the real past, but it is of no consequence to historical research. Should we encounter new, previously unidentified, evidence, we are of course inclined to change the model of the city and the historical past. Nonetheless, we do so only to account for the evidence and its relation 
to the model, we are not changing the real past, nor we are strengthening our correspondence to it. Historical facts change in time, while the real past does not. As Derek Turner states, discussing a similar example from the biology, in his book Making Prehistory:

Understood in this way, the conclusion is true, but it poses no threat to constructivism. On this first interpretation, to say that one fact is in the past relative to another is to say that that the first fact was a fact at an earlier time, and that the second fact was a fact at a later time. (Turner 2007, 153)

The primary aim of the historian is not to explain the past, but to constitute the model based on the present findings, and to explain the various parts of this model. Historians thus inquire into the present, not into the past. The historians do not usually doubt that Caesar was a real person since there is no overwhelming evidence implying that we should think otherwise. It is even better to say, that historians do not ponder over the existence of Caesar since that is not part of their work. Their task is to explain the substantial number of artefacts, texts, or relicts that are known to us. This explanation entails dealing with the fact that some evidence relevant to the given subject in the constituted model might be contradictory, however, this does not interfere with the possibility of producing a unified historical and critical account. Nonetheless, provided we want to produce comprehensive and detailed biography of Caesar and we seek to overcome contradictory evidence, we must accept that our overarching image of Caesar is just a useful fiction that helps us to accommodate contemporary data. In other cases, fragmented evidence seemingly referring to the same person may be disregarded as too vague and contradictory, therefore hindering the historical inquiry. Such cases can be described by historians as more legendary than historical characters. When we refer to an historical agent, we, in fact, refer to an entity inside a model (a constituted historical past). This is not the result of an historical character's demise, but of fragmentary and often contradictory nature of historical evidence that is treated by historians who are often producing vastly diverging accounts of historical agents. Diverse historiographical texts and interpretations are also portraying still living characters and it could be even said that their authors engage in debates with their contenders by putting forward pieces of evidence and arguing historically. Historical agents are evaluated 
and described by the hypothetical references to their intentions and according to the impact they supposedly have on the historical past. Those are, however, later constructs.

The historians are fully aware of their dependence on the present evidence and its theory-laden identification. The following passage from the contemporary book on Ancient Greek history and on the life of Spartan kings Agis and Cleomenes III nicely illustrates the point. I believe that the passage is worth quoting at full length:

Written, documentary texts that might correct or supplement the opposed tendencies of the two principal literary sources are very thin on the ground. Numismatic and other material testimony tends in this case to illustrate and sometimes illuminate the literary picture rather than form the basis for an alternative account. This is partly because of the selective nature of the data we have. For example, the absence of archaeological corroboration of the literary picture of private affluence cannot be used to overthrow it, given the lack of finds from graves or private dwellings in Sparta. In short, the evidentiary situation is such that too often we cannot say for certain what events actually occurred or in what order, and usually we can only attempt to guess why. The immense modern bibliography on Agis and Cleomenes may suitably reflect the objective and symbolic importance of their reigns but it is inversely proportional to our sure knowledge of them. (Cartledge et al. 2005, 35-36)

The authors are aware of the fact that limited evidence underdetermines the results of their inquiry and that their conclusions are not infallible, however, there is still a substantial amount of empirical data present and it demands an explanation. Historical evidence can be explained only historically by constituting appropriate historical past (appropriate model), otherwise, it will remain unexplained.

Since the historical antirealism considers history to be an inquiry into the present world and since the historical past is a fiction explaining present phenomena, we must necessarily ask what phenomena and objects are eligible for historical explanation. During the second half of the twentieth century, historians started to inquire into a virtually unlimited number of 
possible topics. Almost any aspect of human life may be subjected to the historical inquiry: the history of sexuality, history of sports, history of computing, history of comics, etc. At the same time, an historical explanation may have a very mundane form: if we want to explain e.g. a hammer to a child, we may say that it is a blunt tool that is used for driving nails into the wood. However, when we are confronted with a type of tool that is not used today in everyday life, we seek a different kind of explanation. We need to refer to the historical past (not the real past) and to the fictional people that were using this tool in the course of some activates. This process of identifying something as an historical evidence was nicely captured by Goldstein in one of his early works:

When we say that the starting point is the evidence, we mean only that the suspicion that there were events is suggested by the fact that there are present certain things which seem not to fit into the present context of culture and life: writings which most of us cannot read, coins which will buy nothing at the grocery, ruins of buildings and of entire cities, and so on. (Goldstein 1969, 176)

If we positively identify something as the relict of the inaccessible past and if we are able to fit this relict into some timeline (e.g. with the help of chemical analysis), we may then look for other instances of the same type of artefact, which would belong to other periods we use for classification of evidence. Once again it is seen that history explains the present world, not the past itself. The world would go on even without the historians. Nonetheless, without a systematic field of knowledge dedicated to the relicts and traces of the past, we would ascribe the ruins of Roman spas to the dwarves or other mythical beings. Historians would generally agree that they cannot predict the future in the same manner that speculative philosophers of history claim to do, however, they may have the ability to predict where to find some previously unidentified evidence on the basis of another piece of evidence. Upon establishing some prior hypothesis, historians often know which archives they should visit in their search for further evidence. ${ }^{19}$

19 A detailed overview and analysis of such occurrences can be found in (Murphey 2009, 40-46). 
The historical past consists of fictional, abstract, and idealised entities we may call historical facts. Historical facts are not created independent of each other and hermetically sealed inside a factual chronicle ${ }^{20}$ which needs explanation or retelling. On the contrary, when constituting an historical fact, historian already constitutes it in relation to other historical facts. The idea of past facts, suspended in some kind of ideal chronicle, waiting for the historian to explain them or to devise a narrative around them, is not only unattainable, but also misleading. Historical facts are definitely not atomic, historians do not simply build their stories from the sole pre-given blocks and do not explain isolated events by connecting them to others through the help of covering laws. When referring to historical facts, we actually refer to objects in models, not in reality. ${ }^{21}$ Only the past emerged in this process of the historical constitution can become the subject of further intellectual endeavour:

There are, of course, interesting things to be done with a past already emerged. One could explain it; or one could interpret it. And one could contemplate it in the belief that it must surely contain lessons for us that may be put to use as we seek to confront our present and effect our future. (Goldstein 1986, $83)$

Nonetheless, it is true that historian approaches his subject equipped with the preliminary knowledge of the current discourse among the historians. Historians are not constituting their models from scratch and without any relation to other models currently accepted in the community of historians. Historians may seek to re-examine the phenomena accepted as evidence, they may strive to expand the accepted historical theories, or they may try to offer vastly different model meant to explain similar sets of phenomena. This discursive aspect of history as a discipline was only hinted at in the works of Goldstein, however, contemporary philosophers of history (not necessarily antirealists) are becoming progressively more aware of this

20 The idea of chronicle could be considered as inert since it is described as a "mere" collection of meaningless and weltering facts. See (White H. 1975).

21 See a similar statement about the models in physics in (Cartwright 1984, 129). 
aspect pertaining to the historical inquiry. ${ }^{22}$ As historians begin to sprout an interest in new topics like the history of women in politics, history of toys, or history of sports, new and previously unidentified (though available) pieces of evidence become evident. Once again, we may say that historical inquiry is essentially a contemporary inquiry (done by contemporary agents with the help of contemporary tools) into the present (inquiring into the present data labelled as evidence) while producing models explaining the present phenomena through the constitution of historical past. Contemporary agents who conduct this inquiry are present-day historians and they are working within the boundaries of their discipline. There are, of course, disagreements concerning certain peripheral subjects which cannot be easily resolved by calling out the evidence. This is because the evidence only underdetermines the theory or narrative in some cases. However, as Aviezer Tucker points out, there is a significant consensus among the historians about central issues. Tucker devoted a lot of thought to the task of defining the consensus as an epistemically significant factor: "Consensus in a uniquely heterogeneous, large, and uncoerced group of historians is a likely indicator of knowledge" (Tucker 2004, 39).

Historical antirealists could easily accept this statement, although they would swiftly deny that the knowledge indicated in such a way is knowledge of the past. It does rather imply that such knowledge encompasses the present artefacts and relicts and it does offer the best possible explanation of them in the form of a fictional historical past.

Disagreements between historians are about the proper treatment and assessment of the evidence. The competing models of historical pasts often explain the similar sets of present phenomena, however, the appropriate assessment of relevant evidence and its exact role in the course of the historical constitution is not a trivial task. A good example of the fluid nature of historical evidence could be the case of literary forgeries that have appeared in Europe during the $19^{\text {th }}$ century that were intended to promote the patriotism and nationalism, like The Dvůr Králové and Zelená Hora manuscripts, found in 1817 and 1819 respectively. These forgeries have

22 Recently, a Finnish philosopher of history Jouni-Matti Kuukkanen has drawn attention to the discursive and argumentative side of historical endeavour. His current research focuses on the microhistorical epistemology; see (Kuukkanen 2017, 118).

Organon F 26 (4) 2019: 635-659 
depicted the heroic past of the Czech nation and provided a narrative that showed currently subdued nation as proud, civilised, and free people sharing a long and glorious history. At first, these carefully forged manuscripts had been taken as authentic relicts of the past and they did fuel Czech National Revival. However, by the 1880 s, the authenticity of both documents was mostly rejected. This was achieved by analysing the grammatical and metrical structure of the text as well as by the extensive historical research and comparative studies. The forgeries thus ceased to be an evidence about the glorious past of the Czech nation and they become the evidence in the narrative about Czech National Revival illustrating the desperate strive of Czech intellectuals to codify the national identity. Forged manuscripts are still an historical evidence and historians can still utilize them to create a model of Czech National Revival, a model that explains a vast number of diverse texts (novels, poetry, textbooks, historiography, dictionaries, etc.) and artefacts from the $19^{\text {th }}$ century but, on the other hand, it would be entirely inappropriate to include these texts when constituting the historical past of the $9^{\text {th }}$ century Bohemia when taken at face value. There are, of course, other unresolved issues available to the historians of Czech National Revival, they can try to explain the motives behind the forgeries, they can ponder about the ethical issues involved, however, no historian of early medieval Bohemia finds this piece of evidence relevant to the contemporary research.

We can summarise historical antirealism as a thesis that the discipline of history is interested in explaining the present phenomena (texts, artefacts) that require the postulation of historical past to be fully explained. This historical past is a model or set of models created by historians based on the empirical data identified as an evidence. Historians proceed by discovering and identifying new pieces of evidence as well as by adjusting the models to account for previously unaccounted data which could be explained historically.

\section{Caveats against historical antirealism}

It is important to address several common caveats raised against historical antirealism. I will try to answer some of them that may have been the most obvious in the course of this study. 
The crucial issue of historical antirealism is that its rejection of the real past as the touchstone for historical inquiry may seem unwarranted, radical, and unnecessary. We often feel that we know what happened in the past. We generally do not doubt that the Thirty Years' War started in 1618, we never question that Abraham Lincoln was a real man, and we would not deny the usefulness of concepts like the Middle Ages or the Renaissance. However, this very fact that historical antirealism seems so counter-intuitive to us is a result of our unreflected reliance upon the outcomes of historical inquiry. We are accustomed to the history textbooks and canonical historical narratives, but we cannot claim to know the real past. It could be even exaggerated that we are so immersed in historical narratives, that we do not see the real inquiry behind the history. Historians do not directly report the real past to us, they report the results of their interaction with evidence and of their critical thinking about the past they have constituted. Historical antirealism is not motivated by scepticism about the discipline of history. On the contrary, it is motivated by the wish to ward off this scepticism and to show history as a scientific discipline in its own right.

Proponents of historical antirealism are sometimes accused of cherrypicking the examples from the distant past that better suit their theory (see e.g. Nowell-Smith 1977, 4). I can easily see this caveat raised against this paper as well. However, the choice of such examples is motivated by the wish to provide comprehensive and illustrative examples of inquiries where the lack of evidence highlights the very importance of evidence-identification and its treatment. Even when assessing the memories of living witnesses during the interviews or even when utilising video or audio recordings, historians must remain critical and aware of historical methods. It would be a mistake to submit to the illusion that now they know all the relevant facts about the real past event in question. The surplus of contradictory evidence may even complicate matters. At the same time, the cherry-picking should not be a pressing concern, provided all the selected examples are true instances of historical inquiry and historical method. If analytic philosophers of history wish to explain the historical practice, they should consider all instances of historical inquiry equally, especially in the case that given field of history is accepted by the contemporary community of historians. 
Philosophers of science could raise an objection that we are talking about the context of discovery ${ }^{23}$ and ignoring the more philosophically interesting context of justification. However, the context of discovery would imply that something is discovered in the process of historical inquiry and that is not the case according to the historical antirealism. The past is not discovered, the historical past is constituted in order to explain the data discovered before or in the course of an historical inquiry. It would be more appropriate to talk about the context of a constitution. The context of discovery more likely refers to the discovery of artefacts or texts themselves.

The last pressing matter, I would like to address is that by giving up the real past, we are potentially rejecting the value of history as a discipline. If the historical past is fiction, how can we derive any lessons from it? Why should we conduct the historical inquiry?

Apart from the fact that we often derive lessons from fictions and fables $^{24}$ and that many philosophers warned us not to look for some hidden wisdom in history, I would like to claim, that history is even more valuable for historical antirealism since it does explain our world here and now. It is true, that we cannot generally use this fictional knowledge to predict the future or to utilise the findings practically, but we still gain some non-trivial knowledge about the world unattainable in any other way. History can be thus valued as the discipline whose subject is not dead in the past, but it is still present in our time. It does not necessarily follow, that without the history we would be committed to making the same mistakes as our ancestors, but without it, we would have certainly lived in the world where many artefacts and texts would be unaccounted for and our knowledge of the world would be seriously lacking. Even if the historical past that historians present to us is a fictional past, it is still modelled upon the relevant empirical evidence and this process is guided by the highly systematic procedures of the historical discipline. Moreover, the outlined version of historical antirealism is much akin to the philosophical pragmatism since it is concerned with the actual historical practice, the methods of inquiry, and the

23 A similar claim is raised in relation to Paul Roth's non-representationalism by Zeleňák $(2018,125)$.

${ }^{24}$ See Cartwright's distinction between the fables and their morals in comparison to models (Cartwright 1999, 36-40). 
gathering of evidence. Pragmatist considerations are currently being explored by contemporary philosophers of history as they are inquiring into the discourse of professional historians. ${ }^{25}$

Although the discipline of history is naturally understood as an inquiry into the past, it proves to be difficult to maintain the direct link between the contemporary historians and the real event they are supposed to examine, explain, or simply describe. Rather, historians are producing fictional models that are meant to explain present empirical data that would be otherwise inexplicable without the constitution of fictional entities. These entities involve not only abstractions, generalisations, or classifications of historical periods but also the historical agents and events themselves. Historical realism does suffer from the dangers of sceptical objections and criticism. Historical antirealism, though counter-intuitive at first sight, allows historians to retain their competences, to employ various methods, including experimental archaeology or oral history, to produce a broad range of representations, and to successfully pursue various topics through diverse historical subdisciplines. History is shown as an essential field of scientific knowledge that proves its value as an important type of inquiry into our contemporary world. Even though we may consider historical interpretations, theories, or narratives fictional, they are still useful fictions and without them, we would be robbed of large parts of knowledge we possess about the world.

\section{Funding}

The research and the paper are supported by the scientific project IRP201820 "The Construction of the Other in Medieval Europe" (IRP University of Ostrava).

\section{References}

Ankersmit, Frank. 1986. "The Dilemma of Contemporary Anglo-Saxon Philosophy of History." History and Theory 25 (4): 1-27. https://doi.org/10.2307/2505129 Cartledge, Paul, and Antony Spawforth. 2005. Hellenistic and Roman Sparta. London: Routledge. https://doi.org/10.4324/9780203482186

25 See especially (Kuukkanen 2017) and his paper with the expressive title "Moving Deeper into Rational Pragmatism" or (Fay 2017). 
Cartwright, Nancy. 1984. How the Laws of Physics Lie. Oxford: Clarendon Press. https://doi.org/10.1093/0198247044.001.0001

Cartwright, Nancy. 1999. The Dappled World: A Study of the Boundaries of Science. New York: Cambridge University Press. https://doi.org/10.1017/cbo9781139167093

Derek, Turner. 2007. Making Prehistory: Historical Science and the Scientific Realism Debate. Cambridge: Cambridge University Press. https://doi.org/10.1017/cbo9780511487385.007

Fay, Brian. 2017. "From Narrativism to Pragmatism." Journal of the Philosophy of History 11 (1): 11-21. https://doi.org/10.1163/18722636-12341355

Goldstein, Leon J. 1962. "Evidence and Events in History." Philosophy of Science 29 (2): 175-94. https://doi.org/10.1086/287860

Goldstein, Leon J. 1976. Historical Knowing. Austin and London: University of Texas Press.

Goldstein, Leon J. 1986. "Impediments to Epistemology in the Philosophy of History." History and Theory 25 (4): 82-100. https://doi.org/10.2307/2505133

Goldstein, Leon J. 1996. The What and the Why of History: Philosophical Essays. Leiden: Brill.

Guéroult, Martial. 1969. "The History of Philosophy as a Philosophical Problem." The Monist 53 (4): 563-87. https://doi.org/10.5840/monist196953438

Hartmann, Stephan, Carl Hoefer, and Luc Bovens, eds. 2008. Nancy Cartwright's Philosophy of Science. New York: Routledge. https://doi.org/10.4324/9780203895467

Hempel, Carl G. 1942. "The Function of General Laws in History." The Journal of Philosophy 39 (2): 35-48. https://doi.org/10.2307/2017635

Hull, David L. 1975. "Central Subjects and Historical Narratives." History and Theory 14 (3): 253-74. https://doi.org/10.2307/2504863

Hull, David L. 1979. "In Defense of Presentism." History and Theory 18 (1): 1-15. https://doi.org/10.2307/2504668

Hull, David L., and Michael Ruse, eds. 2007. The Cambridge Companion to the Philosophy of Biology. Cambridge: Cambridge University Press. https://doi.org/10.1017/ccol9780521851282

Kuukkanen, Jouni-Matti. 2015. Postnarrativist Philosophy of Historiography. London: Palgrave Macmillan. https://doi.org/10.1057/9781137409874

Kuukkanen, Jouni-Matti. 2017. "Moving Deeper into Rational Pragmatism." Journal of the Philosophy of History 11 (1): 83-118.

https://doi.org/10.1163/18722636-12341362

Lewontin, Richard. 1991. "Facts and the Factitious in Natural Sciences." Critical Inquiry 18 (1): 140-53. https://doi.org/10.1086/448627 
Mandelbaum, Maurice. 1961. "Historical Explanation: The Problem of Covering Laws." History and Theory 1 (3): 229-42. https://doi.org/10.2307/2504314

Mandelbaum, Maurice. 1977. The Anatomy of Historical Knowledge. Baltimore: The John Hopkins University Press. https://doi.org/10.2307/1856346

Murphey, Murray G. 1986. "Explanation, Causes, and Covering Laws." History and Theory 25 (4): 43-57. https://doi.org/10.2307/2505131

Murphey, Murray G. 2009. Truth and History. New York: State University of New York Press.

Nielsen, Margit H. 1981. "Re-Enactment and Reconstruction in Collingwood's Philosophy of History." History and Theory 20 (1): 1-31. https://doi.org/10.2307/2504642

Nowell-Smith, Patrick H. 1977. "The Constructionist Theory of History." History and Theory 16 (4): 1-28. https://doi.org/10.2307/2504805

O'Sullivan, Luke. 2006. "Leon Goldstein and the Epistemology of Historical Knowing." History and Theory 45 (2): 204-28. https://doi.org/10.1111/j.14682303.2006.00357.x

Rosenberg, Alexander. 2000. "Reductionism in a Historical Science." Philosophy of Science 68 (2): 135-63. https://doi.org/10.1002/0470854189.ch7

Rosenberg, Alexander. 2007. "Reductionism (and Antireductionism) in Biology." In The Cambridge Companion to the Philosophy of Biology, edited by David L. Hull and Michael Ruse, 120-38. Cambridge: Cambridge University Press. https://doi.org/10.1017/ccol9780521851282.007

Roth, Paul A. 2012. "The Pasts." History and Theory 51 (3): 313-39. https://doi.org/10.1111/j.1468-2303.2012.00630.x

Roth, Paul A. 2017. "Essentially Narrative Explanations." Studies in History and Philosophy of Science 62: 42-50. https://doi.org/10.1016/j.shpsa.2017.03.008

Tucker, Aviezer. 2001. "The Future of the Philosophy of Historiography." History and Theory 40 (1): 37-56. https://doi.org/10.1111/0018-2656.00151

Tucker, Aviezer. 2004. Our Knowledge of the Past: A Philosophy of Historiography. Cambridge: Cambridge University Press. https://doi.org/10.1017/cbo9780511498381

Tucker, Aviezer, ed. 2009. A Companion to the Philosophy of History and Historiography. Oxford: Blackwell Publishing. https://doi.org/10.1002/9781444304916

Tucker, Aviezer. 2011. "Historical Science, Over- and Underdetermined: A Study of Darwin's Inference of Origins." British Journal for the Philosophy of Science 62 (4): 805-29. https://doi.org/10.1093/bjps/axr012

White, Hayden. 1973. Metahistory: The Historical Imagination in Nineteenth-Century Europe. Baltimore: The Johns Hopkins University Press.

White, Hayden. 1975. "Historicism, History, and the Figurative Imagination." History and Theory 14 (4): 48-67. https://doi.org/10.2307/2504665 
White, Morton. 2005. From a Philosophical Point of View. Princeton: Princeton University Press. https://doi.org/10.1515/9781400826469

Wilkins, John S. 2009. "Darwin." In A Companion to the Philosophy of History and Historiography, edited by Aviezer Tucker, 404-15. Oxford: Blackwell Publishing. https://doi.org/10.1002/9781444304916.ch36

Wright, Georg H. von. 1971. Explanation and Understanding. London: Routledge \& Kegan Paul.

Zeleňák, Eugen. 2018. "Non-Representationalism in Philosophy of History: A Case Study." In Towards a Revival of Analytical Philosophy of History, edited by Krzysztof Brzechczyn, 116-29. Leiden: Brill.

https://doi.org/10.1163/9789004356900_009 